\title{
A COMPARATIVE AROMA AND VOLATILE PROFILE INVESTIGATION OF 2016 AND 2017 VINTAGE BULL'S BLOOD WINE SAMPLES
}

\author{
Gabriella Keresztes - Kitti Bogárdi-Tóth
}

\section{Összefoglalás}

A kisérlet célja az egri Bikavérek aromaprofil felvétele, valamint érzékszervi összevetése volt, ehhez 2016-os és 2017-es Classicus Bikavér mintákat gyüjtöttünk. A vizsgálatok érzékszervi birálatot, GC-MS készülékkel végzett aromaprofil vizsgálatot, valamint WineScan készülékkel az alapparaméterek vizsgálatát foglalta magában. Az érzékszervi vizsgálatoknál szempont volt a bor megjelenése (szin és tisztaság), az illat (intenzitás, fajta karakter, minöség), zamat (intenzitás, fajta karakter, minöség, hosszúság), valamint az összbenyomás a borról. Az aromaprofil vizsgálatokhoz HS-SPME-GCMS technikát használtunk. Az aromák minöségi kiértékelése után statisztikailag értékeltük az eredményeket, amely során négy aroma és egy alap paraméter, valamint az érzékszervi vizsgálatok szempontjai között összefüggést találtunk. Egy aromavegyület pozitiv, a többi negativ irányba befolyásolta az érzékszervi birálatokon adott pontszámokat, mig az alap paraméter pozitiv irányba tolta el a borok megitélését. A kutatási eredményeket késöbbiekben fel lehet használni egy adatbázis létrehozására, valamint vizsgálni a vásárlói attitüdöt.

\begin{abstract}
In our research, our aim was to examine the volatile compounds of Bull's Blood originated from Eger, and search correlation between them and organoleptic analysis. To reach these goals, we collected 2016 vintage and 2017 vintage Bull's Blood samples from different wineries. The research includes organoleptic analysis, volatile compound profile examined with GC-MS, and studying basic parameters, using WineScan. . Organoleptic analysis' points were givens for the look of the wine (colour and clarity), Fragrance (intensity, character and quality), Flavour (intensity, character and quality) and General impression. For examining volatile compounds, we used HS-SPME-GCMS technique, as it is suitable to study aromas. After qualitation of volatile compounds, we used a statistic programme, and there was correlation between four aroma, one basic parameter and some of organoleptic analysis' part. One aroma had positive effect, three aromas has negative effects, and the basic parameter had positive effect on organoleptic analysis.
\end{abstract}




\section{Introduction}

Bull's Blood is a dry, red wine, which is produced in Eger or Szekszárd (Hungary). Bull's Blood, from Eger, is under the protected designation of origin, and since 2017, it is also one of the Hungaricums ${ }^{1}$. It is a blended wine, whose definition states that none of the base wines' characters can dominate the blended whole. There are three types: Classicus, Superior and Grand Superior; differing, for the most part, in their winemaking technology. The Classicus Bull's Blood carries rich, spicy and also fruity notes without heavy tannin tone, due to the unique climate and region. Thirteen types of grapes can be used in the making of this wine: Bíbor kadarka, Blauburger, Cabernet franc, Cabernet sauvignon, Kadarka, Kékfrankos, Kékoportó, Menoir, Merlot, Pinot noir, Syrah, Turán and Zweigelt. Three of them must be used, none of them can make up more than $50 \%$ of the wine and the biggest portion must be Kékfrankos. Classicus also requires half a year of oak aging 2 .

The quality of wine depends on the vintage, the technology, the region and the blending ratios. Except blending ratios, all of these factors affect the aromas which originate from the grape ${ }^{3}$. They can be primer, prefermentative, fermentative or aging aromas. Wine aromas has various classes of compounds such as alcohols, terpene alcohols, esters, aldehydes, ketones, acids and ethers ${ }^{4}$. The blended wines are not made with fragrant grape types and they contain mostly the prefermented aromas 5 . These aromas are C6-aldehydes and alcohols and they give a greeny smell and taste to wine $e^{5}$. During fermentation, the temperature is essential, as yeast has different esterase activity at lower and higher temperature. At lower temperature (10 ${ }^{\circ} \mathrm{C}$ ), fruit esters like isobutyl- isoamyl and hexyl-acetate are produced, however, at higher temperature $\left(15-20^{\circ} \mathrm{C}\right)$ yeast produces higher molecular weighted esters like ethyl-octanoate and ethyl-decanoate. ${ }^{5}$

\section{Material and methods}

Our aim was to compare volatile components of different vintages of Bull's Blood wines and perform organoleptic analysis, as aromas are key ingredients when costumers choose wine.

Several Bull's Blood samples were collected from different wineries, we concentrated on classicus, 2016 and 2017 vintage Bull's Blood samples. We collected 10 samples of 2016 vintage and 10 samples of 2017 vintage. The samples had to be ready-to-bebottled and they were in $0,7 \mathrm{~L}$ bottles. We stored them in room temperature $\left(20^{\circ} \mathrm{C}\right)$ and in a dark place until the examinations were performed. We marked each of them with a 2-digit number from 1 to 20 (1-10: 2016 vintage, 11-20: 2017 vintage). 
Wine samples were studied with the Headspace-SPME method. A 50/30um DVB/ CARV/PDMS, Stableflex SPME fiber is used from Supelco. The bottles were opened just before the examination, $8 \mathrm{~mL}$ wine samples were placed into a $20 \mathrm{~mL}$ Headspace bottles. 3,00 g of $\mathrm{NaCl}$ (AnalR Normapur, a.r.) were placed into the Headspace bottles and were heated to $180^{\circ} \mathrm{C}$ for 24 hours to eliminate contamination. The samples were held in place for 20 minutes at constant temperature $\left(40^{\circ} \mathrm{C}\right)$. The wine samples were stirred with a magnetic stirrer in order to guarantee the even temperature and help the volatile component to transfer into the headspace phase from the sample phase. The SPME fiber was injected to the headspace phase and the volatile components were absorbed for 20 minutes at a constant temperature $\left(40^{\circ} \mathrm{C}\right)$. The SPME fiber was conditioned in GC inlet before every usage by a conditioning programme (injector temp.: $250^{\circ} \mathrm{C}$, start temp.: $100{ }^{\circ} \mathrm{C}$ for $1 \mathrm{~min}$, final temp.: $250^{\circ} \mathrm{C}$ for $25 \mathrm{~min}$ ) in order to eliminate the contamination. After the absorbing phase, the fiber is inserted to GC injector (injection temp.: $250^{\circ} \mathrm{C}$ ) with a 1 minute sampling time.

The measurement was performed with a Shimadzu GC-2010S gas chromatograph equipped with mass spectrometer. We used a $60 \mathrm{~m} \times 25 \mathrm{~mm}$ VF-WAXms highperformance polyethylene glycol column with a $0,25 \mu \mathrm{m}$ film thickness, as it is ideal for flavour and fragrance applications. Injection was splitless and we used Helium as a carrier gas. A specific GC-MS programme was used for separation: initial temperature $40^{\circ} \mathrm{C}$ (4 minutes hold); first ramp $3^{\circ} \mathrm{C} /$ minute to $70{ }^{\circ} \mathrm{C}$ ( 0 minute hold); second ramp $5^{\circ} \mathrm{C} /$ minute to $240{ }^{\circ} \mathrm{C}$ (hold 27 minutes), total programme time: $75 \mathrm{~min}$ ).

We carried out an organoleptic analysis by a panel of 5 tasters. They had to give points based on the appearance of the wine (clarity and colour), fragrance (intensity, character and quality), flavour (intensity, character, quality and lengthiness) and general impression. The subtotal of the maximum points possible was 100 .

Sample ID:

Taster:

\begin{tabular}{|r|r|c|c|c|c|c|}
\hline \multicolumn{2}{|c|}{} & Perfect & Very good & Good & Okay & Not okay \\
\hline \multirow{3}{*}{ Appearance } & clarity & 5 & 4 & 3 & 2 & 1 \\
\cline { 2 - 8 } & colour & 10 & 8 & 6 & 4 & 2 \\
\hline \multirow{3}{*}{ Fragrance } & intensity & 8 & 7 & 6 & 4 & 2 \\
\cline { 2 - 8 } & character & 6 & 5 & 4 & 3 & 2 \\
\cline { 2 - 8 } & quality & 16 & 14 & 12 & 10 & 8 \\
\hline \multirow{3}{*}{ Flavour } & intensity & 8 & 7 & 6 & 4 & 2 \\
\cline { 2 - 8 } & character & 6 & 5 & 4 & 3 & 2 \\
\cline { 2 - 8 } & quality & 22 & 19 & 16 & 13 & 10 \\
\cline { 2 - 7 } & lengthiness & 8 & 7 & 6 & 5 & 4 \\
\hline \multicolumn{2}{|c|}{ General impression } & 11 & 10 & 9 & 8 & 7 \\
\hline
\end{tabular}

1. Figure: The evaluative sheet of organoleptic analysis 
We wanted to know if basic parameters like ethanol, total acid content, volatile acid content, $\mathrm{pH}$, amount of glycerine, the common acids in wine (malic acid, citric acid, lactic acid, sorbic acid, tartaric acid) and sugars (fructose, glucose) are responsible for the different points in an organoleptic analysis, so we measured these parameters with FT-IR (FOSS Winescan).

\section{Results and discussion}

One of our aims was to compare the amount of different volatile components to each other, so we identified them manually, in a compound by compound identification by their $\mathrm{m} / \mathrm{z}$ value using NIST database.

We could find 43 different components, mostly alcohols, esters and acids (2. Table). Methyl decenoate, Furfuryl-alcohol and ethyl-sorbate were only found in 3 separate samples. 1-Octen-3-ol was specific to 2017 vintage, and Only 14 of the components (Ethyl acetate, Isobutyl alcohol, Isoamyl acetate, Isoamyl alcohol, Ethyl caproate, Ethyl lactate, 1-Hexanol, Ethyl octanoate, Ethyl decanoate, Diethyl succinate, Phenethyl alcohol, Octanoic acid) could be found in every single Bull's Blood wine $e^{6,7,8}$.

After identifying, statistical analysis was made by the IBM SPSS 10.0 statistical programme, where we made normality test and we examined the relationship between the volatile components, the basic parameters and the given points of organoleptic analysis (average of the points where examined with SPSS). Mostly, the volatile components have normal distribution, but there were 18 components, whose distribution was not normal (they were those, that we found only in just 1-3 wine samples). Therefore, we used the Pearson correlation where there was normal distribution and Spearman's where there was no normal distribution. Testing the correlation was successful; there were 5 mild correlations, 4 of them were from the results of gas chromatography and one of them was from the basic parameters. 


\section{Table: Correlations between organoleptic analysis and volatile components found by GC-MS}

\section{Correlations}

\begin{tabular}{|c|c|c|c|c|c|c|c|}
\hline & & $\begin{array}{l}\text { Fragrance } \\
\text { intensity }\end{array}$ & $\begin{array}{l}\text { Fragrance } \\
\text { character }\end{array}$ & $\begin{array}{l}\text { Fragrance } \\
\text { quality }\end{array}$ & \begin{tabular}{|l} 
Flavour \\
intensity
\end{tabular} & $\begin{array}{l}\text { Flavour } \\
\text { character }\end{array}$ & $\begin{array}{l}\text { Flavour } \\
\text { quality }\end{array}$ \\
\hline \multirow[t]{4}{*}{$\begin{array}{l}\text { Pearson } \\
\text { Correlation }\end{array}$} & $\begin{array}{l}\text { Tartaric } \\
\text { acid }\end{array}$ & 0,182 & 0,213 & 0,191 & $0,468^{*}$ & 0,206 & 0,175 \\
\hline & $\begin{array}{l}\text { Isoamyl } \\
\text { alcohol }\end{array}$ & 0,413 & $0,448^{*}$ & $0,467^{*}$ & 0,343 & 0,233 & 0,381 \\
\hline & 1-nonanol & $-0,226$ & $-0,474^{*}$ & $-0,555^{*}$ & $-0,435$ & $-0,525^{*}$ & $-0,650^{* *}$ \\
\hline & $\begin{array}{l}\text { Isoamyl } \\
\text { octanoate }\end{array}$ & $-0,296$ & $-0,480^{*}$ & $-0,376$ & $-0,329$ & $-0,496^{*}$ & $-0,509^{*}$ \\
\hline $\begin{array}{l}\text { Spearman's } \\
\text { rho }\end{array}$ & $\begin{array}{l}\text { Isoamyl } \\
\text { lactate }\end{array}$ & $-0,530^{*}$ & $-0,481^{*}$ & $-0,302$ & $-0,363$ & $-0,299$ & $-0,474^{*}$ \\
\hline
\end{tabular}

**. Correlation is significant at the 0.01 level (2-tailed).

*. Correlation is significant at the 0.05 level (2-tailed).

The first one differs from the last four, as it is a basic parameter of wine. Tartaric acid is common in wine, but if wine contains too much of this acid, it gives the wine a piercing taste ${ }^{4}$. However, the more amount of tartaric acid, the better points given to flavour intensity $(\mathrm{p}=0,468)$ (within the limits).

The next parameter was isoamyl alcohol, which is one of the 13 components, that were found in all of the samples. It gives a whiskey like odor to wine, and its presence has a positive effect on the fragrance character $(\mathrm{p}=0,448)$ and quality . $(\mathrm{p}=0,467)$

1 -Nonanol is a straight chain alcohol, that has a characteristic rose-orange odor and a slightly fatty, bitter taste reminiscent of orange'. It has a negative effect on fragrance character $(p=-0,474)$ and quality $(p=-0,555)$, flavour character $(p=-0,525)$ and quality $(\mathrm{p}=-0,650)$.

Isoamyl octanoate has negative effect on fragrance character $(\mathrm{p}=-0,480)$, flavour character $(\mathrm{p}=-0,496)$ and quality $(\mathrm{p}=-0,509)$, it has a nutty, oily, apricot-like odor and a fruity, winy, cognac-rum flavor?.

Isoamyl lactate is ester of isoamyl alcohol and lactic acid. It has a fruity, creamy, nutty odor ${ }^{9}$ which is an unlikely smell in wines. In this case, we used Spearman's correlation test. Its presence in the wine gave 5 of the samples worse points in fragrance intensity $(\mathrm{p}=-0,530)$ and character $(\mathrm{p}=-0,481)$, and also has negative effect on flavour quality $(\mathrm{p}=-474)$. 


\section{Conclusion}

This study demonstrates the varieties of volatile compounds found in Bull's Blood wine. Their aromas were examined with GC-MS and it is suitable for qualitative analysis. Results can be used for optimizing wine in order to maximize selling rates.

We want to collect more Bull's Blood samples to make database. This database can be used for spotting adulteration. We also want to carry organoleptic analysis with more people to survey and find correlation between the buyers' attitude and why would they choose that Bull's Blood.

Authors gratefully acknowledge the financial support of the EFOP-3.6.1-16-201600001 „Kutatási kapacitások komplex fejlesztése az Eszterházy Károly Egyetemen”.

\section{References}

[1.] A Magyar Borkönyv előírásai (borászati termékek jelölése és kiszerelése)

[2.] 607/2009/EK bizottsági rendelet

[3.] Gál Lajos: Az egri Bikavér minőségfejlesztésének lehetőségei Downloading: 2020. 01. 10., Corvinus PhD dissertation archive: http://phd.lib.unicorvinus.hu/463/1/de_3501.pdf

[4.] Gy. Vas, K. Koteleky, M. Farkas, A. Dobo, K. Vékey: Fast Screening Method for Wine Headspace Compounds Using Solid-Phase Microextraction (SPME) and Capillary GC Technique (Article in American Journal of Enology and Viticulture · January 1999)

[5.] Eperjesi Imre, Kállay Miklós, Magyar Ildikó: Borászat (1998, ISBN: 9632860756 )

[6.] V. Ivanova-Petropulos, M. Stefova, T. Stafilov, I. Bíró: The user Validation of a Method for Analysis of Aroma Compounds in Red Wine using LiquidLiquid Extraction and GC-MS (Food Analytical Methods 2012. December) https://doi.org/10.1007/s12161-012-9401-y

[7.] M. Csóka, M. Amtmann, D. Ny. Sárdy, M. Kállay, K. Korány:GC-MS Description of the primary aroma structure of two Kadarka wines considered indigenous in Hungary (Journal of Applied Botany and Food Quality 86, $104-112(2013))$ 
[8.] J.Aith Barbará,K. P. Nicollia, É. A. Souza-Silva, A. C. Telles Biasoto,J. E. Welke,C. A. Zinia: Volatile profile and aroma potential of tropical Syrah wines elaborated in different maturation and maceration times using comprehensive two-dimensional gas chromatography and olfactometry (Food Chemistry Volume 308, 2020 March) https://doi.org/10.1016/j.foodchem.2019.125552

[9.] George A. Burdock Ph.D: Fenaroli's Handbook of Flavor Ingredients (Sixth Edition, ISBN: 978-1-4200-9077-2)

\section{Authors}

\section{Keresztes Gabriella}

Eszterházy Károly University,

Food and Wine Research Centre

keresztes.gabriella@uni-eszterhazy.hu

\section{Bogárdi-Tóth Kitti Irén}

Eszterházy Károly University,

Food and Wine Research Centre

toth.kitti@uni-eszterhazy.hu 